\title{
Review of Upflow Anaerobic Sludge Blanket Reactor Technology: Effect of Different Parameters and Developments for Domestic Wastewater Treatment
}

\author{
M. K. Daud (D), ${ }^{1,2}$ Hina Rizvi $\left(\mathbb{D},{ }^{3}\right.$ Muhammad Farhan Akram, ${ }^{3}$ Shafaqat Ali $\left(\mathbb{D},{ }^{3,4}\right.$ \\ Muhammad Rizwan, ${ }^{3}$ Muhammad Nafees, ${ }^{5}$ and Zhu Shui Jin (DD ${ }^{1}$ \\ ${ }^{1}$ Institute of Crop Science, College of Agriculture and Biotechnology, Zhejiang University, Zijingang Campus, Hangzhou, China \\ ${ }^{2}$ Department of Biotechnology and Genetic Engineering, Kohat University of Science and Technology, Kohat 26000, Pakistan \\ ${ }^{3}$ Department of Environmental Sciences and Engineering, Government College University, Allama Iqbal Road, \\ Faisalabad 38000, Pakistan \\ ${ }^{4}$ Key Laboratory of Soil Environment and Pollution Remediation, Institute of Soil Science, Chinese Academy of Sciences, \\ Nanjing 210008, China \\ ${ }^{5}$ Institute of Soil \& Environmental Sciences, University of Agriculture, Faisalabad 38000, Pakistan
}

Correspondence should be addressed to Hina Rizvi; hinarizvil@gmail.com and Zhu Shui Jin; shjzhu@zju.edu.cn

Received 10 July 2017; Revised 25 October 2017; Accepted 14 December 2017; Published 21 January 2018

Academic Editor: Claudio Di Iaconi

Copyright (C) 2018 M. K. Daud et al. This is an open access article distributed under the Creative Commons Attribution License, which permits unrestricted use, distribution, and reproduction in any medium, provided the original work is properly cited.

The upflow anaerobic sludge blanket (UASB) reactor has been recognized as an important wastewater treatment technology among anaerobic treatment methods. The objective of this study was to perform literature review on the treatment of domestic sewage using the UASB reactor as the core component and identifying future areas of research. The merits of anaerobic and aerobic bioreactors are highlighted and other sewage treatment technologies are compared with UASB on the basis of performance, resource recovery potential, and cost. The comparison supports UASB as a suitable option on the basis of performance, green energy generation, minimal space requirement, and low capital, operation, and maintenance costs. The main process parameters such as temperature, hydraulic retention time (HRT), organic loading rate (OLR), $\mathrm{pH}$, granulation, and mixing and their effects on the performance of UASB reactor and hydrogen production are presented for achieving optimal results. Feasible posttreatment steps are also identified for effective discharge and/or reuse of treated water.

\section{Introduction}

The wastewater generated by a community is called "sewage," which is a mixture of domestic wastewater, industrial wastewater (where the industry is discharging its wastewater in the same sewage system), and rain water, where a single sewer system exists for wastewater and storm water [1]. In the developing/underdeveloped countries of the world, more than $90 \%$ of the sewage is discharged untreated in the environment due to lack of proper wastewater collection and treatment facilities. The quantity and strength of wastewater are governed by the size and socioeconomic condition of the population of the area [2]. The composition of sewage varies greatly and its characterization is important for determining the size and designing of treatment plant [3]. Table 1 provides an overview of characteristics of municipal sewage in various cities of the world.

Anaerobic treatment is preferred to treat municipal wastewater because of its merits over conventional treatment methods [1]. These advantages are (i) its ability to treat high COD loads and withstand fluctuation in the influent, (ii) biogas formation, and (iii) effective treatment of wastewater in a short period of time [4]. Anaerobic reactors reduce pollution load and provide good stabilization of solids. Furthermore, depending on the design of a UASB reactor, a high sludge hold-up time can be obtained so that the excess sludge needs to be discharged only once every three to four years [5]. The comparison of aerobic and anaerobic technologies is given in Table 2 . 
TABLE 1: Characteristics of sewage in different cities of the world.

\begin{tabular}{|c|c|c|c|c|c|c|}
\hline \multirow{2}{*}{ Parameters } & \multicolumn{2}{|c|}{ Pakistan [82] } & \multirow{2}{*}{$\begin{array}{c}\text { Palestine } \\
\text { Al Bireh [3] }\end{array}$} & \multirow{2}{*}{$\begin{array}{c}\text { Brazil } \\
\text { Pedregal [1] }\end{array}$} & \multirow{2}{*}{$\begin{array}{c}\text { Columbia } \\
\text { Cali [1] }\end{array}$} & \multirow{2}{*}{$\begin{array}{c}\text { Netherlands } \\
\text { Bennekom [1] }\end{array}$} \\
\hline & Karachi & Lahore & & & & \\
\hline BOD & $220-475$ & $200-215$ & - & 368 & 95 & 231 \\
\hline $\mathrm{COD}$ & $200-1400$ & $580-803$ & 1586 & 727 & 267 & 520 \\
\hline Chlorides & $300-1200$ & $32-72$ & - & 110 & - & - \\
\hline Sulfates & $50-200$ & - & - & 18 & - & 15 \\
\hline $\mathrm{NH}_{4}^{+}-\mathrm{N}$ & - & - & 80 & 34 & 17 & - \\
\hline Nkj-N & - & - & 104 & 44 & 24 & - \\
\hline Total P & - & - & 13 & 11 & 1.3 & 18 \\
\hline $\mathrm{PO}_{4}^{-3}-\mathrm{P}$ & - & - & 12.9 & 8 & - & 14 \\
\hline TDS & $1000-1800$ & $486-598$ & - & - & - & - \\
\hline TSS & $250-900$ & $106-176$ & 736 & 492 & 215 & - \\
\hline VSS & - & - & 617 & 252 & 107 & - \\
\hline Temperature & - & - & - & $24-26$ & $24-27$ & $8-20$ \\
\hline
\end{tabular}

TABLE 2: Comparison of aerobic and anaerobic treatment methods.

\begin{tabular}{|c|c|c|c|}
\hline Parameter & Aerobic treatment & Anaerobic & References \\
\hline Process & $\begin{array}{c}\text { Degradation of organic matter occurs in } \\
\text { the presence of oxygen }\end{array}$ & $\begin{array}{c}\text { Degradation of organic matter occurs in } \\
\text { the absence of oxygen }\end{array}$ & [83] \\
\hline By-products & $\begin{array}{l}\text { The process generates carbon dioxide, } \\
\text { water, and excess biomass }\end{array}$ & $\begin{array}{l}\text { The process generates carbon dioxide, } \\
\text { methane, and excess biomass }\end{array}$ & {$[44,84]$} \\
\hline Applicability & $\begin{array}{l}\text { Highest removal efficiency for wastewater } \\
\text { having low to medium organic content } \\
(\mathrm{COD}<1000 \mathrm{ppm}) \text { that is complex to } \\
\text { biodegrade, for example, municipal } \\
\text { sewage and refinery wastewater }\end{array}$ & $\begin{array}{c}\text { Highest removal efficiency for wastewater } \\
\text { having medium to high organic content } \\
(\mathrm{COD}>1000 \mathrm{ppm}) \text { and easy } \\
\text { biodegradability, for example, food and } \\
\text { beverage industry's wastewater rich in } \\
\text { organic content. But also applicable to } \\
\text { low strength wastewater (COD }>300 \text { and } \\
<1000 \mathrm{mg} / \mathrm{L})\end{array}$ & {$[25,85]$} \\
\hline Reaction kinetic & Decay rate $k_{d}=0.06 \mathrm{~d}^{-1}$ & Decay rate $k_{d}=0.03 \mathrm{~d}^{-1}$ & {$[44,83,84]$} \\
\hline $\begin{array}{l}\text { Sludge yield coefficient } \\
\text { (kgVSS/Kg COD) }\end{array}$ & $\begin{array}{l}0.35-0.45 \text { (relatively high) Biomass yield } \\
\text { is fairly constant irrespective of the type } \\
\text { of substrate metabolized }\end{array}$ & $\begin{array}{l}0.05-0.15 \text { (relatively low) biomass yield is } \\
\text { not constant and varies with the type of } \\
\text { substrate metabolized }\end{array}$ & {$[86]$} \\
\hline Posttreatment & $\begin{array}{l}\text { Direct discharge, followed by } \\
\text { filtration/disinfection }\end{array}$ & Generally done by aerobic methods & {$[21,83,87,88]$} \\
\hline Foot print & $\begin{array}{c}1.0 \text { to } 2.4 \mathrm{kgCO}_{2} / \mathrm{kgCOD} \text { removed } \\
\text { (depending on the wastewater strength) }\end{array}$ & $\begin{array}{c}0.5 \text { to } 1.0 \mathrm{KgCO}_{2} / \mathrm{kgCOD} \text { removed } \\
\text { (depending on the wastewater strength) }\end{array}$ & {$[44,45,85,89]$} \\
\hline Capital cost & 12-40 US\$/inhab. & 40-65 US\$/inhab. & {$[49,90-92]$} \\
\hline Typical technologies & $\begin{array}{l}\text { Activated sludge, trickling filters, } \\
\text { extended aeration, oxidation ditch, } \\
\text { downflow hanging sponge (DHS), } \\
\text { Membrane Bioreactor (MBR), Moving } \\
\text { Bed Bioreactor (MBBR) }\end{array}$ & $\begin{array}{l}\text { UASB, continuously stirred tank } \\
\text { reactor/digester/Upflow Anaerobic } \\
\text { Filters, ultrahigh rate fluidized bed } \\
\text { reactors, hybrid high rate reactors, } \\
\text { two-stage UASB reactor }\end{array}$ & {$[15,24,60,67]$} \\
\hline
\end{tabular}

The major achievement in the development of anaerobic treatment was the introduction of high rate reactors in which biomass retention and liquid retention were not interlinked [5]. Among the various anaerobic wastewater treatment technologies, upflow anaerobic sludge blanket (UASB) reactors have achieved considerable success and these reactors have been applied to treat a wide range of effluents such as sugar, pulp and paper, dairy, chemical, potato starch, bean balancing, soft drinks, fish processing, noodle processing, yeast production, slaughterhouse, and coffee processing industries [6-8]. The UASB process was developed by Lettinga and coworkers in the late 1970s [6]. It is primarily used for the treatment of highly concentrated industrial wastewaters [7-9]; however, it can also be used for the treatment of low strength wastewater such as municipal wastewater with relatively lower contaminant strength [1014]. As compared to aerobic technologies anaerobic treatment systems such as UASB are being encouraged because of several advantages, including plain design, uncomplicated construction and maintenance, small land requirement, low 
construction and operating cost, low excess sludge production, robustness in terms of COD removal efficiency, ability to cope with fluctuations in temperature, $\mathrm{pH}$ and influent concentration, quick biomass recovery after shutdown, and energy generation in the form of biogas or hydrogen $[1,9,15-$ 19]. These characteristics make UASB a popular wastewater treatment option $[20,21]$ and a large number of researchers have recommended UASB technology for the treatment of sewage wastewater in tropical and subtropical regions [10$12,14,22-24]$.

It is particularly appealing in tropical countries where the comparatively high ambient temperature is nearly optimum for the mesophilic methanogenic bacteria $[11,13]$. Significant efforts were made in the past twenty years to ascertain the mass transfer and kinetic processes going on in the reactor. In this study, the advantages and disadvantages of anaerobic and aerobic bioreactors are highlighted and comparison is made of UASB with other sewage treatment methods to state their feasibility and efficiency in domestic wastewater treatment and identify possible future areas of research. The effects of main process parameters, temperature, HRT, OLR, $\mathrm{pH}$, granulation, and mixing on the performance of UASB reactors and hydrogen production are provided for optimal growth of bacteria and performance of the system. Appropriate posttreatment options are also identified to be potentially used in developing countries having appropriate climate conditions.

\section{Upflow Anaerobic Sludge Blanket Reactor Process}

Wastewater to be treated is introduced from the bottom of the reactor and it flows upward through a blanket of biologically activated sludge, which is generally in the form of granular aggregates. The sludge aggregates have very good stability and do not get washed out under practical conditions and therefore provide good treatment efficiency when the wastewater comes in contact with the granules [25]. The gases (methane and carbon dioxide) produced under anaerobic conditions cause internal mixing, which helps in the formation and maintenance of biological granules. However, some of the gas produced in the sludge blanket is attached to the granules, and a gas-liquid-solid separator (GLSS) is added on the top of the reactor for the effective segregation of gas, liquid, and granules. In GLSS, the gas surrounded particles strike with the bottom of degassing baffles and fall back into the sludge blanket and the treated water flows out of the reactor $[21,26,27]$.

There is lower gas production in sewage as compared to high strength wastewater, which leads to less circulation of gas to support the formation of biological granules. Therefore, control of channeling is important for weaker wastewaters like sewage $[6,13]$.

\section{Treatment Potential of UASB Process}

UASB technology has been effectively used for the treatment of a wide range of wastewaters but is generally inhibited by incomplete biodegradability of complex wastewaters $[10,28]$.
The UASB technology has been found to be very effective for the treatment of wastewater with a high content of carbohydrates. Carbohydrate rich organic wastewater, such as starch or canning industry wastewater is easily digested by microbes and is thus a nutrient-rich starting material for anaerobic hydrogen production. Upflow anaerobic sludge blanket (UASB) reactor has therefore turned out to be one of the most popular designs for the treatment of wastewaters from food processing industries. Anaerobic reactors have the ability to withstand variations in wastewater quality and complete shutdown of reactor in off season [28, 29]. Fang analyzed the microscopic (SEM and TEM) examinations of biogranules sampled from different UASB reactors. The microbial distribution in granules was found strongly dependent on the thermodynamics of degradation and kinetics of particular substrates. Biogranules degrading carbohydrates had a layered distribution in which the surface layer was occupied by hydrolytic/fermentative acidogens; the mid-layer consisted of syntrophic colonies and interior layer was comprised of acetotrophic methanogens, whereas substrates having a ratelimiting hydrolytic/fermentative step did not have a layered structure and bacteria were distributed evenly. The results reveal that granules are developed through evolution process and not through random aggregation of suspended microbes [29]. Moreover, as supported by experimental evidence biogranules degrading carbohydrates are more resistant than suspended sludge to the toxicity of hydrogen sulfide, heavy metals, and aromatic pollutants in wastewater [30].

About half the organic matter content in domestic wastewater is attributable to black water having a major portion of nutrients. High rate UASB reactors are popular and have been applied widely due to their ability to manage high OLRs, short HTRs, and low energy requirements [31, 32]. A number of full-scale plants are operational and several others are at present under construction, especially in tropical or subtropical areas [33, 34]. Table 3 summarizes the advantages and disadvantages of UASB reactor. Basic concept of UASB technique is to build up anaerobic sludge that has good settling characteristics [1] and that can hold highly active bacterial aggregation without the requirement for immobilization on a support material [35]. About $60 \%$ of the fullscale anaerobic treatment plants operating worldwide are currently based on the UASB design model, treating a wide range of industrial wastewaters $[7,8,36,37]$. About 793 UASB reactors are installed worldwide showing the widest application of this technology out of total of approximately 1229 other anaerobic applications which include anaerobic contact filter, Expanded Granular Sludge Bed (EGSB) reactor, hybrid reactor, and fluidized bed. About half of these installations (338 out of 793) are in tropical and subtropical regions [38]. Table 4 shows the performance of UASB reactors as compared to other technologies. On the basis of overall low investment and $\mathrm{O}$ and $\mathrm{M}$ costs, satisfactory COD, BOD, and TSS removal, and energy generation potential, this technology is suitable as compared to other technologies especially in developing countries. New research studies in this area have proven the successful operation of this system to treat low strength wastewater $[12,39]$. The concentration of COD in domestic wastewater is usually low and suspended solids are high along 
TABLE 3: Advantages and disadvantages of UASB reactor technology.

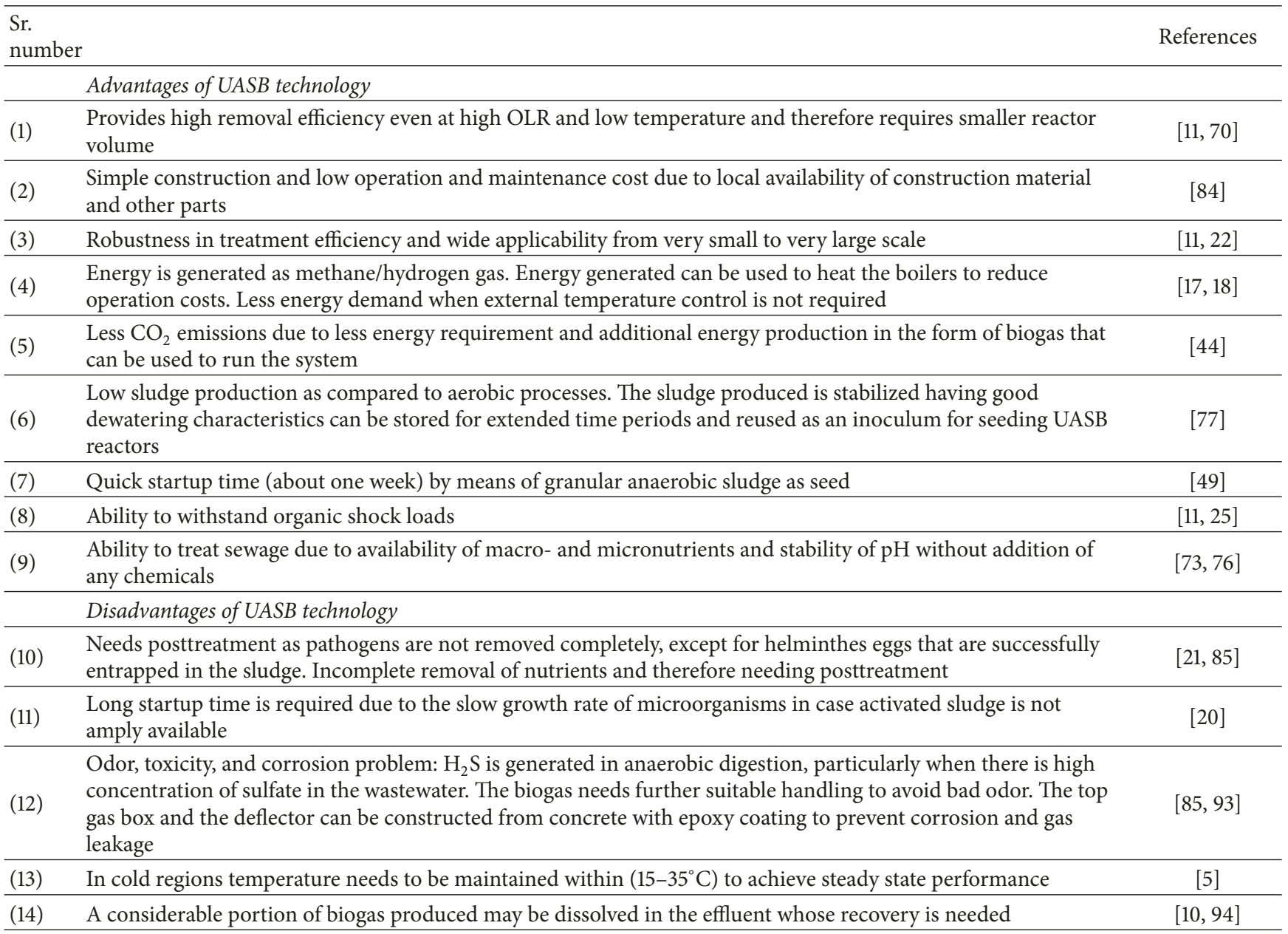

with low methane yield that requires initial hydrolysis to convert the suspended solids into soluble substrate. Hydrolysis is commonly the limiting step at low temperature setting. Therefore, the UASB reactors for domestic wastewater treatment having high level of suspended solids are practicable only at higher temperature which may require an outside heat source $[32,40]$. Better process understanding and operational knowledge on granules structure have made it possible to apply high organic loads and resulted in reducing startup time and providing a more sustainable operation [40, 41]. Its performance in the world proves it to be a consistent and efficient system for wastewater treatment [1].

\section{Resource Recovery Potential}

Anaerobic technologies have the ability to recover the chemical energy of organic carbon in wastewater as methane, hydrogen, and electricity. In UASB reactor, solids are captured and organic matter is converted into biogas consisting largely of methane and carbon dioxide. Organically bound nitrogen is transformed to ammonium and sulfate is reduced to hydrogen sulfide. Moreover, sludge generation is low and sludge produced is highly stable with good dewaterability characteristics [42]. Under aerobic conditions, there is a complete loss of biomass energy in low value heat during the oxidation of organic matter, whereas under anaerobic degradation process, the original energy of the biomass is not changed. About $13.5 \mathrm{MJ}$ of energy is stored in one kilogram COD. Depending on the extent to which anaerobic conversion is permitted, this energy is captured in the form of methane, hydrogen, other gases, or liquid compounds such as alcohols. Energy recovery is an old process which exists as alcohol fermentation and is now renewed by the production of biofuels from organically rich substrates [43]. In terms of carbon foot print, anaerobic wastewater treatment is more advantageous, based on the relative efficiency of the aerobic system (Table 2). In case of effluent having low strength (BOD less than $300 \mathrm{mg} / \mathrm{L}$ ), aerobic process is favorable, as it generates less greenhouse gas. But, in case of wastewater having higher strength (BOD more than $300 \mathrm{mg} / \mathrm{L}$ ) anaerobic treatment is more beneficial. The recovery of dissolved methane in effluents in an economic way makes anaerobic wastewater treatment favorable in reducing carbon foot print for all wastewater strengths $[44,45] . \mathrm{CH}_{4}$ produced in the reactor should always be used for energy production and methane dissociation in the effluent and sulfate reduction 


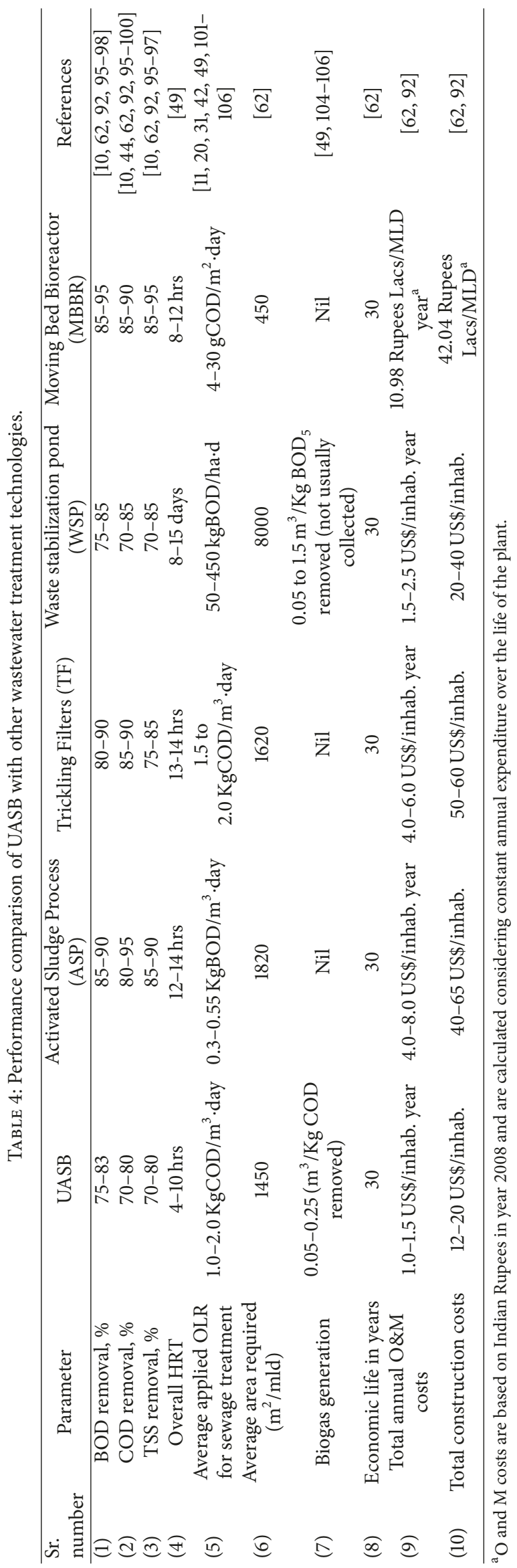


must be examined. About $20 \%$ of the $\mathrm{CH}_{4}$ produced is dissolved in the effluent at ambient temperature of $20^{\circ} \mathrm{C}$ and biogas having methane content of $70 \%$. As a result the benefits of energy production are reduced significantly. Nonetheless, diffusion of methane is high at low temperatures (less than $18^{\circ} \mathrm{C}$ ) and it can be removed easily by a stripping chamber or air diffusion [46]. In case of high sulfate or sulfite content, sulfate reducing bacteria compete with the methanogens for methanogenic substrates and therefore the amount of methane generated is decreased [3]. In the United States and other developed countries, methane generated from anaerobic digestion is combusted for energy production, at large treatment plants, and is at least flared and converted to $\mathrm{CO}_{2}$ at smaller plants [47]. Increased biogas production, efficient biogas usage, and in turn decreased addition of external fossil will lead to reduction of carbon footprint of a wastewater treatment plant [48].

Hydrogen produced in anaerobic fermentation is a clean, carbon-free energy carrier gas, a substitute for fossil fuel, that is considered to play a main role in the future hydrogen based economy due to its high energy yield $(122 \mathrm{~kJ} / \mathrm{g})$. The major problem in hydrogen production from biological processes is the low production rates and hydrogen yield at a large scale. Present research on hydrogen fermentation is directed towards determining culture details, beneficial substrates, conditions affecting microbial conversions, sequential fermentation, combined fermentation, mixed culture fermentation, optimizing enrichment, and stability of acidogenic sludge and reaction kinetics $[49,50]$. Acetate (HAc), butyrate $(\mathrm{HBu})$, caproate $(\mathrm{HCa})$, propionate $(\mathrm{HPr})$, and lactate $(\mathrm{HLa})$ make up the metabolic pathways involved in the acidogenesis process in the UASB reactor for hydrogen production. HAc, $\mathrm{HBu}$, and $\mathrm{HCa}$ are the desirable metabolites by-products for hydrogen production pathways. On the other hand, HLa and HPr are undesirable and consuming hydrogen pathways [51]. A number of studies have been done on the generation of biohydrogen from food processing industries' wastewater; however very few studies have been carried out on hydrogen production from domestic wastewater. Potential of hydrogen production is now being realized by using domestic wastewater in anaerobic reactors $[52,53]$. Fernandes et al. [53] reported hydrogen yield of $200 \mathrm{ml} \mathrm{H}_{2}$ /gCOD by using domestic sewage as substrate in anaerobic reactor. Similarly, Paudel et al. [52] reported hydrogen yields of $1.014 \mathrm{~mol} \mathrm{H}_{2} / \mathrm{mol}$ glucose at $3 \mathrm{~g} \mathrm{COD} / \mathrm{L}$ day loading rate using synthetic domestic wastewater. The operational conditions play a crucial role in hydrogen production. A $\mathrm{pH}$ of about 5.0-5.5 is reported to favor hydrogen production as the intermediates produced in the reactor can form appropriate ratios and stimulate the metabolism of particular microbes responsible for hydrogen fermentation. For both high rate hydrogen production and organics removal, organic acids generated in effluent can be methanized in a methanogenic reactor after hydrogenic reactor and energy generated from hydrogen may be utilized in posttreatment units where anaerobic reactor is the core technology for sewage treatment [53].

Factors such as inoculum, temperature, OLR, HRT, and $\mathrm{pH}$ must be taken into account for optimal hydrogen production. Use of inoculum previously adapted to hydrogen production greatly enhances hydrogen rate and yield as compared to nonadapted one. In mixed culture, hydrogen producing bacteria may consume the hydrogen produced and they need to be removed to curtail hydrogen consumers and enrich hydrogen producers [52-54]. Previous studies do not show an optimal range of HRT and OLR in fermentative hydrogen production due to varying environmental process parameters or ranges of the variables reported in literature. The OLR can be optimized only when the microbes are well acclimatized to the applied OLR. The optimum temperature for hydrogen production through dark fermentation depends on the type of hydrogen producing bacteria and carbon source used [55]. Hydrogen producing bacteria belong to mesophilic and thermophilic groups and generally rate of hydrogen production increases with increase in temperature through thermophilic bacteria compared to mesophilic bacteria [56].

$\mathrm{Mu}$ and $\mathrm{Yu}$ [57] demonstrated that hydrogen could be generated continuously and steadily from an acidogenicgranule-based UASB reactor at varying concentration of substrate (5.33-28.07 g-COD/L) and HRTs of 3-30 h, during treatment of sucrose-rich synthetic wastewater. They found that $\mathrm{H}_{2}$ partial pressure in biogas decreased with increasing substrate concentration; however it was not affected by the change of HRT in a range of 6-22 h. The rate of hydrogen production increased with increasing substrate concentration but decreased with increasing HRT with a hydrogen yield in the range of $0.49-1.44 \mathrm{~mol}-\mathrm{H} 2 / \mathrm{mol}$ glucose [47].

Furthermore, research is underway on directly producing electric current from electrons released in anaerobic fermentation. These electrons are scavenged at an anode and with the use of cathode under oxidizing conditions electric current is generated which can be used in decentralized plants directly without any further conversion process $[58,59]$.

\section{Posttreatment Requirements}

The UASB reactors do not warrant the removal of remaining organic matter, nutrients, and pathogens. Therefore, posttreatment of anaerobically treated wastewater is usually required in order to improve the quality of effluent in accordance with the irrigation standards. This has been successfully done by conventional systems such as maturation ponds, waste stabilization ponds, polishing ponds, constructed wetlands, rotating biological contactors, moving bed biofilm reactor, downflow hanging sponge [60-62], and advanced oxidative processes (AOPs) [63, 64].

Polishing ponds are natural systems mainly for removal of solids which have been effectively used for the posttreatment of upflow anaerobic sludge blanket (UASB) effluents. They are mainly used as maturation ponds for the removal of pathogens, nitrogen, and remaining organic matter from the UASB reactor effluent [65]. The use of sequential anaerobicaerobic technology such as UASB-activated sludge for municipal wastewater treatment combines the benefits of both systems in an economical arrangement. The combined system is energy efficient, less sludge producer, and relatively less complex for domestic wastewater treatment as compared to other options. An added advantage is the biological oxidization of 
the dissolved methane; however, the overall greenhouse gas reduction will depend on the energy consumption of aerobic step $[44,66]$. The UASB and posttreatment system can be applied consecutively or in an integrated manner.

\section{Effect of Different Parameters on the Efficiency of UASB Reactor}

The efficiency of UASB reactors is regulated by a large number of factors including wastewater characteristics, acclimatization of seed sludge, $\mathrm{pH}$, nutrients, presence of toxic compounds, loading rate, upflow velocity $\left(V_{\text {up }}\right)$, hydraulic retention time (HRT), liquid mixing, and reactor design that affect the growth of sludge bed [16, 67-69].

\section{Effect of Temperature}

Temperature considerably influences the growth and survival of microorganisms. Anaerobic treatment is possible at all three temperature ranges (psychrophilic, mesophilic, and thermophilic); however, low temperature generally leads to a decline in the maximum specific growth rate and methanogenic activity $[39,70,71]$. Methanogenic activity at this temperature range is 10 to 20 times lower than the activity at $35^{\circ} \mathrm{C}$, which requires an increase in the biomass in the reactor (10 to 20 times) or operating at higher sludge retention time (SRT) and hydraulic retention time (HRT) in order to achieve the same COD removal efficiency as that obtained at $35^{\circ} \mathrm{C}[3,67]$.

It is argued that the decrease of temperature slows down the hydrolysis and decreases the maximum growth and substrate utilization rates [5]. Singh et al. [72] treated municipal wastewater using a UASB system under low temperature conditions and reported 70\% COD removal at $11^{\circ} \mathrm{C}$ and 30 to $50 \%$ at $6^{\circ} \mathrm{C}$. Lew et al. [40] found a gradual decrease in COD removal efficiency as the temperature was decreased. They reported $82 \% \mathrm{COD}$ removal at $28^{\circ} \mathrm{C}, 72 \%$ at $20^{\circ} \mathrm{C}, 68 \%$ at $14^{\circ} \mathrm{C}$, and $38 \%$ at $10^{\circ} \mathrm{C}$. Kalogo and Verstraete [73] also found that $\mathrm{COD}$ removal efficiency at temperature in the range of $10-15^{\circ} \mathrm{C}$ was lower than that of efficiency at $35^{\circ} \mathrm{C}$.

Van Lier and Lettinga [74] studied the effect of transient temperature rise on the performance of a UASB reactor containing mesophilic microorganisms. There was an increase in the methane production with an increase in the temperature due to the accelerated methanogenic activity. However, a sharp drop in the methane generation was noted at the reactor temperature exceeding $45^{\circ} \mathrm{C}$ because of a substantial decline in the activity of mesophilic granular sludge due to bacterial inactivation. Halalsheh et al. [75] treated high strength sewage $(\mathrm{COD}=1531 \mathrm{mg} / \mathrm{L})$ using a UASB pilot plant under subtropical conditions. The $\mathrm{COD}_{\text {tot }}$ removal efficiencies were $62 \%$ and $51 \%$ in summer and winter, respectively, when the plant was operated at ambient temperature $\left(18-25^{\circ} \mathrm{C}\right)$ and hydraulic retention time of 24 hours.

\section{Effect of Hydraulic Retention Time (HRT)}

Hydraulic retention time (HRT) is one of the most important parameters affecting the performance of the reactor especially in case of municipal wastewater $[76,77]$. The upflow velocity $\left(V_{\text {up }}\right)$ is directly related to HRT and plays an important role in entrapping suspended solids. A decrease in $V_{\text {up }}$ entails an increase in HRT, which boosts suspended solids' (SS) removal efficiency of the system $[1,78,79]$. The COD removal efficiency of a UASB reactor also decreases at elevated upflow velocity because higher $V_{\text {up }}$ reduces the contact time between sludge and wastewater in addition to smashing of sludge granules and resultantly higher washout of solids $[3,11$, 80]. However, some scientists reported no distinct effect of HRT on the treatment efficiency of UASB reactor [22, 77]. The difference of opinion in scientific community is attributable to the difference in the reactor design, operating procedures, and range of HRT. Flow rate is also a key operational parameter that maintains the hydraulic retention time. In UASB process, if diameter of reactor will be too large then it may cause liquid channeling in the reactor leading to insufficient contact between the substrate and biomass. Therefore, large reactor will result in decreased biogas production and sludge washout due to insufficient mixing within the reactor. In contrast, comparatively more height may promote substrate mixing leading to proper contact of substrate with microorganisms resulting in more organic matter degradation and formation of biogas [81].

The upflow velocity $\left(V_{\text {up }}\right)$ is helpful in providing adequate mixing of the substrate and biomass without channeling and maintaining the hydraulic retention time. The allowable limit of upflow velocity is $0.5-1.5 \mathrm{~m} / \mathrm{h}$ as reported by different researchers. For the treatment of municipal wastewater in UASB reactor, researchers have reported successful operation at $0.31-0.426 \mathrm{~m} / \mathrm{h} V_{\text {up }}$ at 3-4 h of HRT [32, 75].

\section{Effect of Organic Loading Rate (OLR)}

OLR is the main parameter significantly affecting microbial ecology and functioning of UASB process. In case of sewage, the OLR usually is applied in the range of $1.0-2.0 \mathrm{KgCOD} / \mathrm{m}^{3}$. day $[42,101]$. UASB reactor is preferred for its potential to treat wastewater having low content of suspended solids and gives higher methane yield [27]. The reactors seeded with granular activated sludge can give high performance within a brief startup period and can also adapt quickly to increase of OLR [25]. The effect of OLR on the performance of a UASB reactor depends on a number of factors which sometimes have a dissimilar effect, mostly contradictory, on the performance of UASB reactor [11]. Researchers have reported an increase in the efficiency of high rate anaerobic reactors with increasing OLR [107]. However, that increase is up to a certain OLR, beyond which there occurs sludge bed flotation and excessive foaming in the gasliquid-solids separator (GLSS); therefore a range of optimum OLR is usually recommended for a given temperature range and wastewater [108]. Seghezzo [10] operated pilot-scale UASB reactors with OLR of $0.6 \mathrm{kgCOD} / \mathrm{m}^{3}$.day (HRT of 6 hours and COD influent $=153 \mathrm{mg} / \mathrm{L}$ ) and achieved maximum $63 \%$ COD removal efficiency at a low temperature of $17^{\circ} \mathrm{C}$. Farajzadehha et al. [108] carried out a study on a lab-scale UASB reactor for determining the optimal organic loading rate and hydraulic retention time. Substrate used was fortified 
municipal wastewater at volumetric organic loadings of 3.6, $7.2,10.8$, and $14.4 \mathrm{kgCOD} / \mathrm{m}^{3}$. day and temperature of 30 and $20^{\circ} \mathrm{C}$. The results indicated an optimal organic loading rate range of 7.2 to $10.8 \mathrm{kgCOD} / \mathrm{m}^{3}$. day at both temperature conditions attaining COD removal efficiency of $85 \%$ and $73 \%$ in UASB reactor at $30^{\circ} \mathrm{C}$ and $20^{\circ} \mathrm{C}$, respectively. Nitrate removal efficiency was about $80 \%$ at optimized organic loading rate and there was a $30 \%$ decrease in nitrate removal efficiency when OLR was increased to $14.4 \mathrm{kgCOD} / \mathrm{m}^{3}$.day. Halalsheh [22] determined the performance of UASB reactors for treatment of strong domestic wastewater at OLR of approximately $1.5 \mathrm{kgCOD} / \mathrm{m}^{3} \cdot$ day $(\mathrm{COD}$ influent $=1500 \mathrm{mg} / \mathrm{L})$ with a high portion of suspended solids (about 80\%) at HRT of 24 hours. Even at considerably long HRT, the reactor achieved a COD removal efficiency of only $62 \%$ in summer $\left(25^{\circ} \mathrm{C}\right)$. The comparatively low efficiency was caused by the sludge washout. Higher than optimal OLR results in the accumulation of biogas in the sludge bed forming gas pockets that ultimately cause sludge flotation [25]. Leitao [11] determined the effect of influent concentration, HRT, and OLR on the COD removal efficiency of UASB reactors employed to treat sewage. Eleven (11) pilot-scale UASB reactors were divided into three sets. In first set, five reactors were operated at constant HRT of $6 \mathrm{hrs}$ and with different $\mathrm{COD}_{\text {Inf }}(92-816 \mathrm{mg} / \mathrm{L})$ and corresponding OLR ranging from 0.2 to $3.3 \mathrm{kgCOD} / \mathrm{m}^{3}$. day. In second set, four reactors were operated with approximately the same $\mathrm{COD}_{\text {Inf }}(\sim 800 \mathrm{mg} / \mathrm{L})$ but different HRTs $(1,2$, 4 , and $6 \mathrm{hrs}$ ) and corresponding OLR ranging from 3.3 to $17.6 \mathrm{kgCOD} / \mathrm{m}^{3}$.day. In third set, HRTs were same as second set but the $\mathrm{COD}_{\operatorname{Inf}}$ was modified $(136-816 \mathrm{mg} / \mathrm{L})$ to have approximately the same organic loading rate (OLR $3.3 \mathrm{kgCOD} / \mathrm{m}^{3}$. day) in the four reactors. Results revealed that although the reactors of third set were operated with same OLR $\left(3.3 \mathrm{~kg} \mathrm{COD} / \mathrm{m}^{3}\right.$.day) and different HRTs and $\mathrm{COD}_{\text {Inf }}$, they resulted in completely different COD removal efficiency varying from 13 to 57\%. According to Leitao [11], as OLR is dependent on wastewater strength, upflow velocity, and volume of reactor, it is thus also dependent on the applied HRT. Therefore, impact of OLR on reactor performance is not simple, as it is dependent on other parameters, which have opposing effects on the removal efficiency of UASB; that is, increasing the feed concentration from 98 to $818 \mathrm{mg} / \mathrm{L}$ (and hence OLR of 0.4 to $3.3 \mathrm{kgCOD} / \mathrm{m}^{3}$.day) up to a certain limit (OLR of $1.2 \mathrm{~kg} \mathrm{COD} / \mathrm{m}^{3}$.day) caused an increase in removal efficiency (50 to 64\%), whereas increasing the flow rate (and therefore OLR from 3.3 to $17.6 \mathrm{~kg} \mathrm{COD} / \mathrm{m}^{3}$.day) caused a decrease in total COD efficiency from 57 to $36 \%$.

In the case of effluent having COD contents lower than $300 \mathrm{mg} / \mathrm{L}$ (OLR: 0.4 to $0.8 \mathrm{kgCOD} / \mathrm{m}^{3}$.day), the COD removal efficiency of UASB reactors was low (50-53\%). However, reactors showed maximum COD removal efficiency of $64 \%$ when the COD concentration of influent was around $300 \mathrm{mg} / \mathrm{L}$ (OLR $1.2 \mathrm{kgCOD} / \mathrm{m}^{3}$. day). At higher influent COD concentration ( 300 to $816 \mathrm{mg} / \mathrm{L}$ ) and corresponding OLR of 2.2 to $3.3 \mathrm{kgCOD} / \mathrm{m}^{3} \cdot$ day, the COD removal remained in the range of 57 to $60 \%$. A decrease in SS removal as COD efficiency from 97 to $90 \%$ of UASB reactors with an increase in influent COD concentration from 92 to $816 \mathrm{mg} / \mathrm{L}$ and in turn OLR from 0.4 to $3.3 \mathrm{kgCOD} / \mathrm{m}^{3}$.day was reported [11]. When the increase in OLR ( 0.4 to $3.3 \mathrm{kgCOD} / \mathrm{m}^{3}$. day) is due to an increase in the influent COD contents, a sharp decrease in SS removal efficiency may occur. That decrease owes to SS washout caused by turbulence due to higher rate of gas production. When the increase in OLR is associated with decreasing HRT (increase of flow rate), a decline in SS removal efficiency may occur due to sludge washout and short contact time between sludge bed and substrate, which results in the malfunctioning of physical and biological processes taking place in the reactor. However, SS removal efficiency of the reactor decreases to less extent when increase in OLR is associated with increased SS contents of substrate [11]. Miron [109] reported an increase in SS removal with an increase in OLR associated with higher influent SS. These differences among the research workers are due to use of primary sludge by Miron to increase OLR. Primary sludge is mainly comprised of settleable suspended solids which increased the SS removal efficiency and therefore reported higher SS removal [11, 108, 109].

Thus, in order to describe the performance of UASB for treatment of sewage, the OLR has to be examined along with $\mathrm{HRT}$ and/or $\mathrm{COD}_{\text {Inf }}$ as advised by Mahmoud [3]. It is however clear from these studies that increasing the OLR will cause a decrease in efficiency of suspended solids removal. However, at a certain OLR, the efficiency of UASB would be optimal in case of long HRT and high COD load of influent (up to a certain limit). When the solids removal efficiency in UASB is related to the OLR, it is important to differentiate between these parameters. It is therefore inferred that OLR is an insufficient design parameter to guarantee good performance of anaerobic reactors [42].

\section{Effect of $\mathrm{pH}$}

The $\mathrm{pH}$ of an anaerobic reactor is especially important because methanogenesis process can proceed at a high rate only when the $\mathrm{pH}$ is maintained in the range of 6.3-7.8 [110]. In the case of domestic sewage, $\mathrm{pH}$ naturally remains in this range because of the buffering capacity of the acidbase system (carbonate system), and addition of chemical is not required [1]. The UASB reactors employed for sewage treatment in tropical and subtropical countries are reported to be extremely stable in terms of $\mathrm{pH}$ and buffering capacity $[10-12,14,22,24,111]$. Improvement in both hydrolysis and acidogenesis rates is achieved when treating domestic wastewater using anaerobic reactor and $\mathrm{pH} 7$ provides an optimal working environment for anaerobic digestion resulting into more than $80 \%$ TOC and COD removal [111].

\section{Effect of Granulation}

In UASB reactor, long HRTs have been found disadvantageous for the development of granular sludge [107, 112]. In contrast, very short HRTs lead to washout of biomass. Both situations are unacceptable for achieving optimum results from UASB reactor. Even though granulation has been considered essential for successful treatment of domestic 
wastewater in UASB reactors, these reactors are found to be effective even without granules. The formation of granules in startup is helpful in shortening startup time $[41,113,114]$. The high performance of the UASB reactor is based on the formation of an active sludge in the lower part of the reactor. The development of sludge bed occurs by the accumulation of incoming suspended solids and bacterial growth under specific conditions, due to the natural aggregation of bacteria in flocs and evolution of granules in the form of layered structure $[29,115]$. These granules are not washed out from the reactor during operation of UASB. The diameter of the granulated sludge particles has been found in the range of 1.0 to $3.0 \mathrm{~mm}[8,116-118]$. The granular suspensions have greater settling velocities $\left(20-80 \mathrm{mh}^{-1}\right)$ as compared to upflow velocities $\left(V_{\text {up }}=0.1-1.0 \mathrm{mh}^{-1}\right)$. Therefore, substantial quantity of biomass can accumulate in the reactor. Consequently, a high sludge loading rate (SLR) could be applied (up to 5 gCODgVSS $^{-1}$ day $^{-1}$ ) with a relatively short HRT, less than 4 hours [25]. Formation of activated sludge is important, in either granular or flocculent form, in the reactor which ensures adequate removal efficiency even at high OLR [27].

\section{Effect of Mixing}

Mixing offers effective contact time to microbes and wastewater, decreases hurdles of transfer of mass, lowers the growth of repressive by-products, and provides uniform environmental conditions. If mixing is not proper, the main process rate will be hampered by pockets of substrate at separate digestion stages, consequently leading to $\mathrm{pH}$ and temperature changes at every stage [119]. Mixing can be achieved mechanically or by recirculation of methane gas or slurry. A number of researchers have observed that significant mixing affects the working of anaerobic reactors. Mixing enhanced efficiency of anaerobic systems treating wastewater with high COD concentration; moreover the recirculation of slurry exhibited better results as compared to biogas recirculation and impeller mixing mode [120].

Mixing also provides increased biogas production as compared to unmixed digesters [120]. Discontinuous mixing is beneficial over energetic mixing when it is applied in large municipal and farm waste digesters [119]. Formation of sludge granules occurs due to fluidization. Vigorous mixing is not recommended as methanogens are less effective in these conditions [121]. Similarly, Karim et al. [120] reported that mixing in startup period lowers the digester $\mathrm{pH}$, resulting in unstable performance and prolonged startup period.

\section{Conclusions and Future Research Areas}

UASB has been successfully applied for the treatment of industrial wastewater with high organic content and municipal wastewaters with high COD load in countries having temperate climatic conditions. Depending on the sewerage system, the sewage wastewater stream may contain toxic substances. Buildup of this matter can affect reactor performance. Overall UASB technology has been found successful for treating domestic wastewater. Therefore these reactors should be installed on priority basis in small communities and towns especially in developing countries with suitable climate conditions. In sewage treatment, the modeling of anaerobic digestion and obtaining higher yield of hydrogen from domestic wastewater have been active research areas in the last few years. The modification of UASB reactor, sequential use of UASB reactor with activated sludge/sequencing batch reactor/septic tank, flash aeration, two-stage UASB reactor/anaerobic filter/hybrid reactor, use of cosubstrate, posttreatment of UASB reactor for pathogen removal and reuse options, kinetics reactions and transfer of mass in anaerobic granular sludge, generation of high methane content, sludge profiling of UASB reactor at various OLRs, modeling for anaerobic granulation, and hydraulics and performance evaluation have been some of active research areas in this field. Modeling of UASB for performance evaluation will be very useful in directing future research on UASB system for direct treatment of wastewater.

\section{Conflicts of Interest}

The authors declare no conflicts of interest.

\section{References}

[1] A. C. Haandel and G. Lettinga, Anaerobic Sewage Treatment: A Practical Guide for Regions with A Hot Climate, John Wiley and Sons, Chichester, UK, 3rd edition, 1994.

[2] M. Henze and A. Ledin, "Types, characteristics and quantities of classic, combined domestic wastewaters," 2004.

[3] N. Mahmoud, Anaerobic pre treatment of sewage under low temperature $\left(15^{\circ} \mathrm{C}\right)$ conditions in an integrated UASB-Digester system, Department of Environmental Technology and the Department of Agro Technology and Food Sciences Wageningen University, Wageningen, The Netherlands, 2002.

[4] P. S. James and S. Kamaraj, "Immobilized cell anaerobic bioreactors for energy production from agro-industrial waste watersAn introduction," Bioenergy News, vol. 6, no. 3, article 10, 2002.

[5] G. Lettinga, S. Rebac, and G. Zeeman, "Challenge of psychrophilic anaerobic wastewater treatment," Trends in Biotechnology, vol. 19, no. 9, pp. 363-370, 2001.

[6] E. Metcalf and I. Eddy, Wastewater Engineering Treatment and Reuse, McGraw-Hill Education, New York, NY, USA, 4th edition, 2003.

[7] A. Farghaly and A. Tawfik, "Simultaneous hydrogen and methane production through multi-phase anaerobic digestion of paperboard mill wastewater under different operating conditions," Applied Biochemistry and Biotechnology, vol. 181, no. 1, pp. 142-156, 2017.

[8] K. Yetilmezsoy and S. Sakar, "Development of empirical models for performance evaluation of UASB reactors treating poultry manure wastewater under different operational conditions," Journal of Hazardous Materials, vol. 153, no. 1-2, pp. 532-543, 2008.

[9] L. Singh, Z. A. Wahid, M. F. Siddiqui, A. Ahmad, M. H. A. Rahim, and M. Sakinah, "Application of immobilized upflow anaerobic sludge blanket reactor using Clostridium LS2 for enhanced biohydrogen production and treatment efficiency of palm oil mill effluent," International Journal of Hydrogen Energy, vol. 38, no. 5, pp. 2221-2229, 2013. 
[10] L. Seghezzo, Anaerobic Treatment of Domestic Wastewater in Subtropical Regions, Wageningen University, Wageningen, The Netherlands, 2004.

[11] R. C. Leitao, Robustness of UASB Reactors Treating Sewage under Tropical Conditions, Wageningen University, Wageningen, The Netherlands, 2004.

[12] H. Rizvi, N. Ahmad, F. Abbas et al., "Start-up of UASB reactors treating municipal wastewater and effect of temperature/sludge age and hydraulic retention time (HRT) on its performance," Arabian Journal of Chemistry, vol. 8, no. 6, pp. 780-786, 2015.

[13] A. A. Khan, I. Mehrotra, and A. A. Kazmi, "Sludge profiling at varied organic loadings and performance evaluation of UASB reactor treating sewage," Biosystems Engineering, vol. 131, pp. 3240, 2015.

[14] S. M. Mgana, Towards Sustainable And Robust Community on Site Domestic Wastewater [Phd Thesis], Wageningen University, Wageningen, The Netherlands, 2003.

[15] T. A. Elmitwalli, K. L. T. Oahn, G. Zeeman, and G. Lettinga, "Treatment of domestic sewage in a two-step anaerobic filter/anaerobic hybrid system at low temperature," Water Research, vol. 36, no. 9, pp. 2225-2232, 2002.

[16] W. R. Abma, W. Driessen, R. Haarhuis, and M. C. M. Van Loosdrecht, "Upgrading of sewage treatment plant by sustainable and cost-effective separate treatment of industrial wastewater," Water Science and Technology, vol. 61, no. 7, pp. 1715-1722, 2010.

[17] P. Kongjan, S. O-Thong, and I. Angelidaki, "Hydrogen and methane production from desugared molasses using a twostage thermophilic anaerobic process," Engineering in Life Sciences, vol. 13, no. 2, pp. 118-125, 2013.

[18] M. Hernández and M. Rodríguez, "Hydrogen production by anaerobic digestion of pig manure: Effect of operating conditions," Journal of Renewable Energy, vol. 53, pp. 187-192, 2013.

[19] H. Rizvi, S. Ali, A. Yasar, M. Ali, and M. Rizwan, "Applicability of upflow anaerobic sludge blanket (UASB) reactor for typical sewage of a small community: its biomass reactivation after shutdown," International Journal of Environmental Science and Technology, pp. 1-12, 2017.

[20] J. A. Álvarez, I. Ruiz, M. Gómez, J. Presas, and M. Soto, "Startup alternatives and performance of an UASB pilot plant treating diluted municipal wastewater at low temperature," Bioresource Technology, vol. 97, no. 14, pp. 1640-1649, 2006.

[21] S. Chong, T. K. Sen, A. Kayaalp, and H. M. Ang, "The performance enhancements of upflow anaerobic sludge blanket (UASB) reactors for domestic sludge treatment-a State-of-theart review," Water Research, vol. 46, no. 11, pp. 3434-3470, 2012.

[22] M. Halalsheh, Anaerobic Pre Treatment of Strong Sewage. A Proper Solution for Jordan, Environmental Technology Department Wageningen University: Wageningen Research Center, Wageningen, The Netherlands, 2002.

[23] Q. H. Banihani and J. A. Field, "Treatment of high-strength synthetic sewage in a laboratory-scale upflow anaerobic sludge bed (UASB) with aerobic activated sludge (AS) posttreatment," Journal of Environmental Science and Health, Part A: Toxic/Hazardous Substances and Environmental Engineering, vol. 48, no. 3, pp. 338-347, 2013.

[24] P. F. F. Cavalcanti, Integrated Application of The UASB Reactor And Ponds for Domestic Sewage Treatment in Tropical Regions, Wageningen University, Wageningen, The Netherlands, 2003.

[25] S. V. Kalyuzhnyi, V. I. Sklyar, M. A. Davlyatshina et al., "Organic removal and microbiological features of UASB-reactor under various organic loading rates," Bioresource Technology, vol. 55, no. 1, pp. 47-54, 1996.
[26] G. Zeeman, W. Sanders, and G. Lettinga, "Feasibility of the onsite treatment of sewage and swill in large buildings," Water Science and Technology, vol. 41, no. 1, pp. 9-16, 2000.

[27] R. Shahperi, M. F. M. Din, S. Chelliapan et al., "Optimization of methane production process from synthetic glucose feed in a multi-stage anaerobic bioreactor," Desalination and Water Treatment, vol. 57, no. 60, pp. 29168-29177, 2016.

[28] B. Wolmarans and G. H. De Villiers, "Start-up of a UASB effluent treatment plant on distillery wastewater," Water $S A$, vol. 28, no. 1, pp. 63-68, 2002.

[29] H. H. P. Fang, "Microbial distribution in UASB granules and its resulting effects," Water Science and Technology, vol. 42, no. 12, pp. 201-208, 2000.

[30] G. Kyazze, R. Dinsdale, A. J. Guwy, F. R. Hawkes, G. C. Premier, and D. L. Hawkes, "Performance characteristics of a two-stage dark fermentative system producing hydrogen and methane continuously," Biotechnology and Bioengineering, vol. 97, no. 4, pp. 759-770, 2007.

[31] I. Ruiz, M. Soto, M. C. Veiga, P. Ligero, A. Vega, and R. Blazquez, "Performance of and biomass characterisation in a UASB reactor treating domestic waste water at ambient temperature," 1998.

[32] S. Uemura and H. Harada, "Treatment of sewage by a UASB reactor under moderate to low temperature conditions," Bioresource Technology, vol. 72, no. 3, pp. 275-282, 2000.

[33] W. Zhou, B. Wu, Q. She, L. Chi, and Z. Zhang, "Investigation of soluble microbial products in a full-scale UASB reactor running at low organic loading rate," Bioresource Technology, vol. 100, no. 14, pp. 3471-3476, 2009.

[34] B. Wu and W. Zhou, "Investigation of soluble microbial products in anaerobic wastewater treatment effluents," Journal of Chemical Technology and Biotechnology, vol. 85, no. 12, pp. 1597$1603,2010$.

[35] J. E. Schmidt and B. K. Ahring, "Granular sludge formation in upflow anaerobic sludge blanket (UASB) reactors," Biotechnology and Bioengineering, vol. 49, no. 3, pp. 229-246, 1996.

[36] T. G. Jantsch, I. Angelidaki, J. E. Schmidt, B. E. Braa de Hvidsten, and B. K. Ahring, "Anaerobic biodegradation of spent sulphite liquor in a UASB reactor," Bioresource Technology, vol. 84, no. 1, pp. 15-20, 2002.

[37] K. Karim and S. K. Gupta, "Continuous biotransformation and removal of nitrophenols under denitrifying conditions," Water Research, vol. 37, no. 12, pp. 2953-2959, 2003.

[38] H. Fang and Y. Liu, "Anaerobic wastewater treatment in (sub) tropical regions," in Advances in Water and Wastewater Treatment Technology, T. Matsuo, K. Hanaki, S. Takizawa, and H. Satoh, Eds., vol. 285, 2001.

[39] K. S. Singh, T. Viraraghavan, and D. Bhattacharyya, "Sludge blanket height and flow pattern in UASB reactors: Temperature effects," Journal of Environmental Engineering, vol. 132, no. 8, pp. 895-900, 2006.

[40] B. Lew, I. Lustig, M. Beliavski, S. Tarre, and M. Green, "An integrated UASB-sludge digester system for raw domestic wastewater treatment in temperate climates," Bioresource Technology, vol. 102, no. 7, pp. 4921-4924, 2011.

[41] Y. Liu, H.-L. Xu, S.-F. Yang, and J.-H. Tay, "Mechanisms and models for anaerobic granulation in upflow anaerobic sludge blanket reactor," Water Research, vol. 37, no. 3, pp. 661-673, 2003.

[42] A. Abdelgadir, X. Chen, J. Liu et al., "Characteristics, process parameters, and inner components of anaerobic bioreactors," BioMed Research International, vol. 2014, Article ID 841573, 10 pages, 2014. 
[43] A. C. van Haandel, "Integrated energy production and reduction of the environmental impact at alcohol distillery plants," Water Science and Technology, vol. 52, no. 1-2, pp. 49-57, 2005.

[44] F. Y. Cakir and M. K. Stenstrom, "Greenhouse gas production: A comparison between aerobic and anaerobic wastewater treatment technology," Water Research, vol. 39, no. 17, pp. 4197-4203, 2005.

[45] J. Keller and K. Hartley, "Greenhouse gas production in wastewater treatment: process selection is the major factor," Water Science and Technology, vol. 47, no. 12, pp. 43-48, 2003.

[46] P. F. Greenfield and D. J. Batstone, "Anaerobic digestion: Impact of future greenhouse gases mitigation policies on methane generation and usage," Water Science and Technology, vol. 52, no. 1-2, pp. 39-47, 2005.

[47] H. D. Monteith, H. R. Sahely, H. L. MacLean, and D. M. Bagley, "A life-cycle approach for estimation of greenhouse gas emissions from canadian wastewater treatment," Proceedings of the Water Environment Federation, vol. 2003, no. 11, pp. 514-527, 2003.

[48] D. J. I. Gustavsson and S. Tumlin, "Carbon footprints of Scandinavian wastewater treatment plants," Water Science and Technology, vol. 68, no. 4, pp. 887-893, 2013.

[49] J. B. Van Lier, "High-rate anaerobic wastewater treatment: diversifying from end-of-the-pipe treatment to resource-oriented conversion techniques," Water Science and Technology, vol. 57, no. 8, pp. 1137-1148, 2008.

[50] D. Dionisi and I. M. O. Silva, "Production of ethanol, organic acids and hydrogen: an opportunity for mixed culture biotechnology?" Reviews in Environmental Science and Bio/Technology, vol. 15, no. 2, pp. 213-242, 2016.

[51] A. Mostafa, M. Elsamadony, A. El-Dissouky, A. Elhusseiny, and A. Tawfik, "Biological H2 potential harvested from complex gelatinaceous wastewater via attached versus suspended growth culture anaerobes," Bioresource Technology, vol. 231, pp. 9-18, 2017.

[52] S. Paudel, Y. Kang, Y.-S. Yoo, and G. T. Seo, "Hydrogen production in the anaerobic treatment of domestic-grade synthetic wastewater," Sustainability, vol. 7, no. 12, pp. 16260-16272, 2015.

[53] B. S. Fernandes, G. Peixoto, F. R. Albrecht, N. K. Saavedra del Aguila, and M. Zaiat, "Potential to produce biohydrogen from various wastewaters," Energy for Sustainable Development, vol. 14, no. 2, pp. 143-148, 2010.

[54] Y. Kawagoshi, N. Hino, A. Fujimoto et al., "Effect of inoculum conditioning on hydrogen fermentation and $\mathrm{pH}$ effect on bacterial community relevant to hydrogen production," Journal of Bioscience and Bioengineering, vol. 100, no. 5, pp. 524-530, 2005.

[55] P. Mohammadi, S. Ibrahim, M. S. M. Annuar, S. Ghafari, S. Vikineswary, and A. A. Zinatizadeh, "Influences of environmental and operational factors on dark fermentative hydrogen production: a review," CLEAN-Soil, Air, Water, vol. 40, no. 11, pp. 1297-1305, 2012.

[56] Y. Zhang and J. Shen, "Effect of temperature and iron concentration on the growth and hydrogen production of mixed bacteria," International Journal of Hydrogen Energy, vol. 31, no. 4, pp. 441446, 2006.

[57] Y. $\mathrm{Mu}$ and H.-Q. Yu, "Biological hydrogen production in a UASB reactor with granules. I: Physicochemical characteristics of hydrogen-producing granules," Biotechnology and Bioengineering, vol. 94, no. 5, pp. 980-987, 2006.
[58] Y. Sharma and B. Li, "Optimizing energy harvest in wastewater treatment by combining anaerobic hydrogen producing biofermentor (HPB) and microbial fuel cell (MFC)," International Journal of Hydrogen Energy, vol. 35, no. 8, pp. 3789-3797, 2010.

[59] L. Singh and Z. A. Wahid, "Methods for enhancing biohydrogen production from biological process: A review," Journal of Industrial and Engineering Chemistry, vol. 21, pp. 70-80, 2015.

[60] A. Tawfik, F. El-Gohary, and H. Temmink, "Treatment of domestic wastewater in an up-flow anaerobic sludge blanket reactor followed by moving bed biofilm reactor," Bioprocess and Biosystems Engineering, vol. 33, no. 2, pp. 267-276, 2010.

[61] M. Tandukar, A. Ohashi, and H. Harada, "Performance comparison of a pilot-scale UASB and DHS system and activated sludge process for the treatment of municipal wastewater," Water Research, vol. 41, no. 12, pp. 2697-2705, 2007.

[62] N. Khalil, R. Sinha, A. Raghav, and A. Mittal, "UASB technology for sewage treatment in India: experience, economic evaluation and its potential in other developing countries," in Proceedings of the in Twelfth International Water Technology Conference, 2008.

[63] E. Alonso, A. Santos, and P. Riesco, "Micro-organism re-growth wastewater disinfected by UV radiation and ozone: a microbiological study," Environmental Technology, vol. 25, no. 4, pp. 433-441, 2004.

[64] H. Rizvi, N. Ahmad, A. Yasar, K. Bukhari, and H. Khan, "Disinfection of UASB-treated municipal wastewater by $\mathrm{H} 2 \mathrm{O}$ 2, UV, ozone, PAA, H2O2/sunlight, and advanced oxidation processes: regrowth potential of pathogens," Polish Journal of Environmental Studies, vol. 22, no. 4, pp. 1153-1161, 2013.

[65] T. E. Possmoser-Nascimento, V. A. J. Rodrigues, M. Sperling, and J.-L. Vasel, "Sludge accumulation in shallow maturation ponds treating UASB reactor effluent: results after 11 years of operation," Water Science and Technology, vol. 70, no. 2, pp. 321328, 2014.

[66] M. Von Sperling, V. H. Freire, and C. A. De Lemos Chernicharo, "Performance evaluation of a UASB-activated sludge system treating municipal wastewater," Water Science \& Technology, vol. 43, no. 11, pp. 323-328, 2001.

[67] L. Foresti, "Anaerobic treatment of domestic sewage: established technologies and perspectives," Water Science and Technology, vol. 45, no. 10, pp. 181-186, 2002.

[68] S. J. Zhang, N. R. Liu, and C. X. Zhang, "Study on the performance of modified UASB process treating sewage," Advanced Materials Research, vol. 610-613, pp. 2174-2178, 2013.

[69] F. I. Turkdogan-Aydinol and K. Yetilmezsoy, "A fuzzy-logicbased model to predict biogas and methane production rates in a pilot-scale mesophilic UASB reactor treating molasses wastewater," Journal of Hazardous Materials, vol. 182, no. 1-3, pp. 460-471, 2010.

[70] I. Bodík, B. Herdová, and M. Drtil, "Anaerobic treatment of the municipal wastewater under psychrophilic conditions," Bioprocess Engineering, vol. 22, no. 5, pp. 385-390, 2000.

[71] N. Azbar, F. T. Dokgöz, T. Keskin et al., "Comparative evaluation of bio-hydrogen production from cheese whey wastewater under thermophilic and mesophilic anaerobic conditions," International Journal of Green Energy, vol. 6, no. 2, pp. 192-200, 2009.

[72] K. S. Singh, H. Harada, and T. Viraraghavan, "Low-strength wastewater treatment by a UASB reactor," Bioresource Technology, vol. 55, no. 3, pp. 187-194, 1996. 
[73] Y. Kalogo and W. Verstraete, "Development of anaerobic sludge bed (ASB) reactor technologies for domestic wastewater treatment: motives and perspectives," World Journal of Microbiology and Biotechnology, vol. 15, no. 5, pp. 523-534, 1999.

[74] J. B. Van Lier and G. Lettinga, "Appropriate technologies for effective management of industrial and domestic waste waters: the decentralised approach," Water Science and Technology, vol. 40, no. 7, pp. 171-183, 1999.

[75] M. Halalsheh, Z. Sawajneh, M. Zu'bi et al., "Treatment of strong domestic sewage in a $96 \mathrm{~m} 3$ UASB reactor operated at ambient temperatures: two-stage versus single-stage reactor," Bioresource Technology, vol. 96, no. 5, pp. 577-585, 2005.

[76] R. F. Hickey, W.-M. Wu, M. C. Veiga, and R. Jones, "Startup, operation, monitoring and control of high-rate anaerobic treatment systems," Water Science and Technology, vol. 24, no. 8, pp. 207-255, 1991.

[77] S. M. M. Vieira and A. D. Garcia Jr., "Sewage treatment by UASB-reactor. Operation results and recommendations for design and utilization," Water Science and Technology, vol. 25, no. 7, pp. 143-157, 1992.

[78] R. Rajakumar, T. Meenambal, J. R. Banu, and I. T. Yeom, "Treatment of poultry slaughterhouse wastewater in upflow anaerobic filter under low upflow velocity," International Journal of Environmental Science and Technology, vol. 8, no. 1, pp. 149158, 2011.

[79] R. R. Liu, Q. Tian, B. Yang, and J. H. Chen, "Hybrid anaerobic baffled reactor for treatment of desizing wastewater," International Journal of Environmental Science and Technology, vol. 7, no. 1, pp. 111-118, 2010.

[80] V. N. Nkemka and M. Murto, "Evaluation of biogas production from seaweed in batch tests and in UASB reactors combined with the removal of heavy metals," Journal of Environmental Management, vol. 91, no. 7, pp. 1573-1579, 2010.

[81] M. R. Peña, D. D. Mara, and G. P. Avella, "Dispersion and treatment performance analysis of an UASB reactor under different hydraulic loading rates," Water Research, vol. 40, no. 3, pp. 445-452, 2006.

[82] H. Rizvi, Sewage treatment by an upflow anaerobic sludge blanket reactor (UASB) under subtropical conditions [PhD Thesis], University of the Punjab, Lahore, India, 2011.

[83] N. Sato, T. Okubo, T. Onodera, A. Ohashi, and H. Harada, "Prospects for a self-sustainable sewage treatment system: a case study on full-scale UASB system in India's Yamuna River Basin," Journal of Environmental Management, vol. 80, no. 3, pp. 198207, 2006.

[84] Y. J. Chan, M. F. Chong, C. L. Law, and D. G. Hassell, "A review on anaerobic-aerobic treatment of industrial and municipal wastewater," Chemical Engineering Journal, vol. 155, no. 1-2, pp. 1-18, 2009.

[85] S. C. Oliveira and M. Von Sperling, "Performance evaluation of UASB reactor systems with and without post-treatment," Water Science and Technology, vol. 59, no. 7, pp. 1299-1306, 2009.

[86] S. K. Khanal, Anaerobic Biotechnology for Bioenergy Production: Principles and Applications, John Wiley \& Sons, 2011.

[87] A. A. Khan, R. Z. Gaur, V. K. Tyagi et al., "Sustainable options of post treatment of UASB effluent treating sewage: a review," Resources, Conservation \& Recycling, vol. 55, no. 12, pp. 12321251, 2011.

[88] A. T. Nair and M. M. Ahammed, "The reuse of water treatment sludge as a coagulant for post-treatment of UASB reactor treating urban wastewater," Journal of Cleaner Production, vol. 96, article 3884, pp. 272-281, 2015.
[89] B. D. Shoener, I. M. Bradley, R. D. Cusick, and J. S. Guest, "Energy positive domestic wastewater treatment: the roles of anaerobic and phototrophic technologies," Environmental Sciences: Processes \& Impacts, vol. 16, no. 6, pp. 1204-1222, 2014.

[90] S. Shastry, T. Nandy, S. R. Wate, and S. N. Kaul, "Hydrogenated vegetable oil industry wastewater treatment using UASB reactor system with recourse to energy recovery," Water, Air, \& Soil Pollution, vol. 208, no. 1-4, pp. 323-333, 2010.

[91] G. Lettinga, J. B. Van Lier, J. C. L. Van Buuren, and G. Zeeman, "Sustainable development in pollution control and the role of anaerobic treatment," Water Science and Technology, vol. 44, no. 6, pp. 181-188, 2001.

[92] M. Von Sperling and C. A. De Lemos Chernicharo, Biological Wastewater Treatment in Warm Climate Regions, vol. 1, IWA publishing, 2005.

[93] J. B. Van Lier, A. Vashi, J. Van Der Lubbe, B. Heffernan, and H. Fang, "Anaerobic sewage treatment using UASB reactors: engineering and operational aspects," in Environmental anaerobic technology; applications and new developments, vol. 59, World Scientific, Imperial College Press, London, UK, 2010.

[94] B. C. Crone, J. L. Garland, G. A. Sorial, and L. M. Vane, "Significance of dissolved methane in effluents of anaerobically treated low strength wastewater and potential for recovery as an energy product: a review," Water Research, vol. 104, pp. 520-531, 2016.

[95] N. Sato, T. Okubo, T. Onodera, L. K. Agrawal, A. Ohashi, and H. Harada, "Economic evaluation of sewage treatment processes in India," Journal of Environmental Management, vol. 84, no. 4, pp. 447-460, 2007.

[96] A. Gnanadipathy and C. Polprasert, "Treatment of a domestic wastewater with UASB reactors," Water Science and Technology, vol. 27, no. 1, pp. 195-203, 1993.

[97] C. A. L. Chernicharo and M. Dos Reis Cardoso, "Development and evaluation of a partitioned upflow anaerobic sludge blanket (UASB) reactor for the treatment of domestic sewage from small villages," Water Science and Technology, vol. 40, no. 8, pp. 107113, 1999.

[98] Z. Sawajneh, A. Al-Omari, and M. Halalsheh, "Anaerobic treatment of strong sewage by a two stage system of AF and UASB reactors," Water Science and Technology, vol. 61, no. 9, pp. 2399-2406, 2010.

[99] C. A. L. Chernicharo, P. G. S. Almeida, L. C. S. Lobato, T. C. Couto, J. M. Borges, and Y. S. Lacerda, "Experience with the design and start up of two full-scale UASB plants in Brazil: enhancements and drawbacks," Water Science and Technology, vol. 60, no. 2, pp. 507-515, 2009.

[100] N. Sundaresan and L. Philip, "Performance evaluation of various aerobic biological systems for the treatment of domestic wastewater at low temperatures," Water Science and Technology, vol. 58, no. 4, pp. 819-830, 2008.

[101] X.-G. Chen, P. Zheng, J. Cai, and M. Qaisar, "Bed expansion behavior and sensitivity analysis for super-high-rate anaerobic bioreactor," Journal of Zhejiang University SCIENCE B, vol. 11, no. 2, pp. 79-86, 2010.

[102] O. R. Zimmo, N. P. van der Steen, and H. J. Gijzen, "Effect of organic surface load on process performance of pilot-scale algae and duckweed-based waste stabilization ponds," Journal of Environmental Engineering, vol. 131, no. 4, pp. 587-594, 2005.

[103] H. Salvadó and M. P. Gracia, "Determination of organic loading rate of activated sludge plants based on protozoan analysis," Water Research, vol. 27, no. 5, pp. 891-895, 1993. 
[104] D. H. Liu and B. G. Liptak, Environmental Engineers' Handbook on CD-ROM, CRC Press, 1999.

[105] B. Picot, J. Paing, J. P. Sambuco, R. H. R. Costa, and A. Rambaud, "Biogas production, sludge accumulation and mass balance of carbon in anaerobic ponds," Water Science and Technology, vol. 48, no. 2, pp. 243-250, 2003.

[106] H. Toprak, "Temperature and organic loading dependency of methane and carbon dioxide emission rates of a full-scale anaerobic waste stabilization pond," Water Research, vol. 29, no. 4, pp. 1111-1119, 1995.

[107] T.-T. Ren, Y. Mu, B.-J. Ni, and H.-Q. Yu, "Hydrodynamics of upflow anaerobic sludge blanket reactors," AIChE Journal, vol. 55, no. 2, pp. 516-528, 2009.

[108] S. Farajzadehha, S. Mirbagheri, S. Farajzadehha, and J. Shayegan, "Lab scale study of HRT and OLR optimization in UASB reactor for pretreating fortified wastewater in various operational temperatures," APCBEE Procedia, vol. 1, pp. 90-95, 2012.

[109] Y. Miron, Anaerobic Treatment of Domestic Sewage with a Twostep Uasr-Uasb System, Hebrew University of Jerusalem, 1997.

[110] C. Casserly and L. Erijman, "Molecular monitoring of microbial diversity in an UASB reactor," International Biodeterioration \& Biodegradation, vol. 52, no. 1, pp. 7-12, 2003.

[111] B. Zhang, L.-L. Zhang, S.-C. Zhang, H.-Z. Shi, and W.-M. Cai, "The influence of $\mathrm{pH}$ on hydrolysis and acidogenesis of kitchen wastes in two-phase anaerobic digestion," Environmental Technology, vol. 26, no. 3, pp. 329-339, 2005.

[112] D. J. Batstone, J. L. A. Hernandez, and J. E. Schmidt, "Hydraulics of laboratory and full-scale upflow anaerobic sludge blanket (UASB) reactors," Biotechnology and Bioengineering, vol. 91, no. 3, pp. 387-391, 2005.

[113] J.-H. Tay, H.-L. Xu, and K.-C. Teo, "Molecular mechanism of granulation. I: $\mathrm{H}+$ translocation-dehydration theory," Journal of Environmental Engineering, vol. 126, no. 5, pp. 403-410, 2000.

[114] S. Aiyuk and W. Verstraete, "Sedimentological evolution in an UASB treating SYNTHES, a new representative synthetic sewage, at low loading rates," Bioresource Technology, vol. 93, no. 3, pp. 269-278, 2004.

[115] J.-H. Tay and Y.-G. Yan, "Influence of substrate concentration on microbial selection and granulation during start-up of upflow anaerobic sludge blanket reactors," Water Environment Research, vol. 68, no. 7, pp. 1140-1150, 1996.

[116] H.-H. Chou and J.-S. Huang, "Role of mass transfer resistance in overall substrate removal rate in upflow anaerobic sludge bed reactors," Journal of Environmental Engineering, vol. 131, no. 4, pp. 548-556, 2005.

[117] R. G. Veronez, A. A. Orra, R. Ribeiro, M. Zaiat, S. M. Ratusznei, and J. A. D. Rodrigues, "A simplified analysis of granule behavior in ASBR and UASB reactors treating low-strength synthetic wastewater," Brazilian Journal of Chemical Engineering, vol. 22, no. 3, pp. 361-369, 2005.

[118] A. Vlyssides, E. M. Barampouti, and S. Mai, "Determination of granule size distribution in a UASB reactor," Journal of Environmental Management, vol. 86, no. 4, pp. 660-664, 2008.

[119] P. Kaparaju, I. Buendia, L. Ellegaard, and I. Angelidakia, "Effects of mixing on methane production during thermophilic anaerobic digestion of manure: lab-scale and pilot-scale studies," Bioresource Technology, vol. 99, no. 11, pp. 4919-4928, 2008.

[120] K. Karim, R. Hoffmann, K. T. Klasson, and M. H. Al-Dahhan, "Anaerobic digestion of animal waste: Effect of mode of mixing," Water Research, vol. 39, no. 15, pp. 3597-3606, 2005.
[121] S. R. Guiot, A. Pauss, and J. W. Costerton, "A structured model of the anaerobic granule consortium," Water Science and Technology, vol. 25, no. 7, pp. 1-10, 1992. 

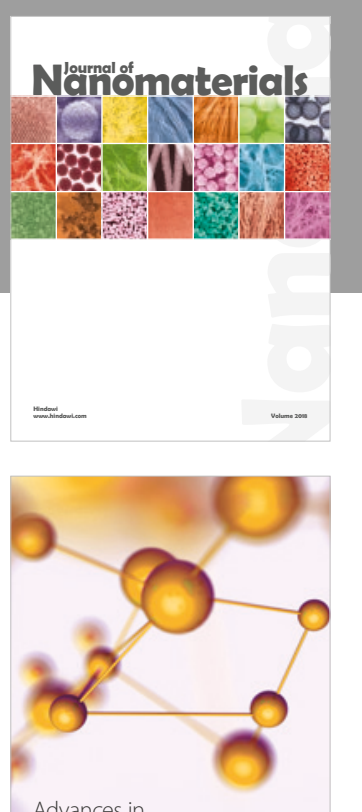

Physical Chemistry
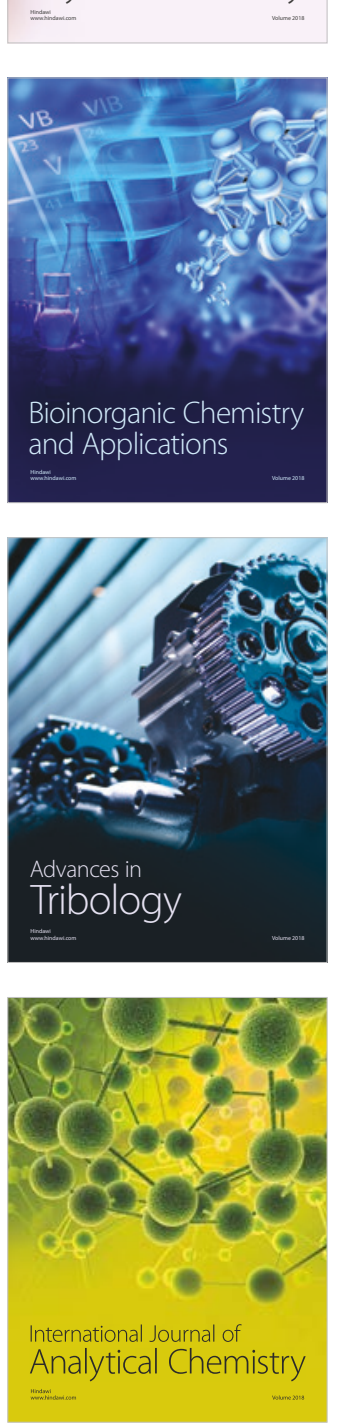



Analytical Methods

in Chemistry

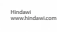

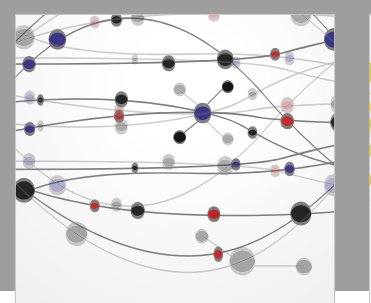

The Scientific World Journal

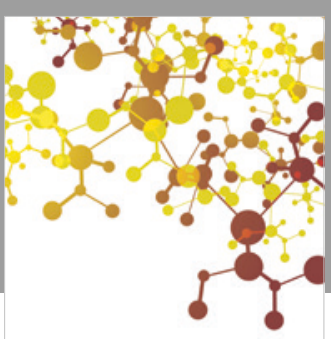

Journal of

Applied Chemistry
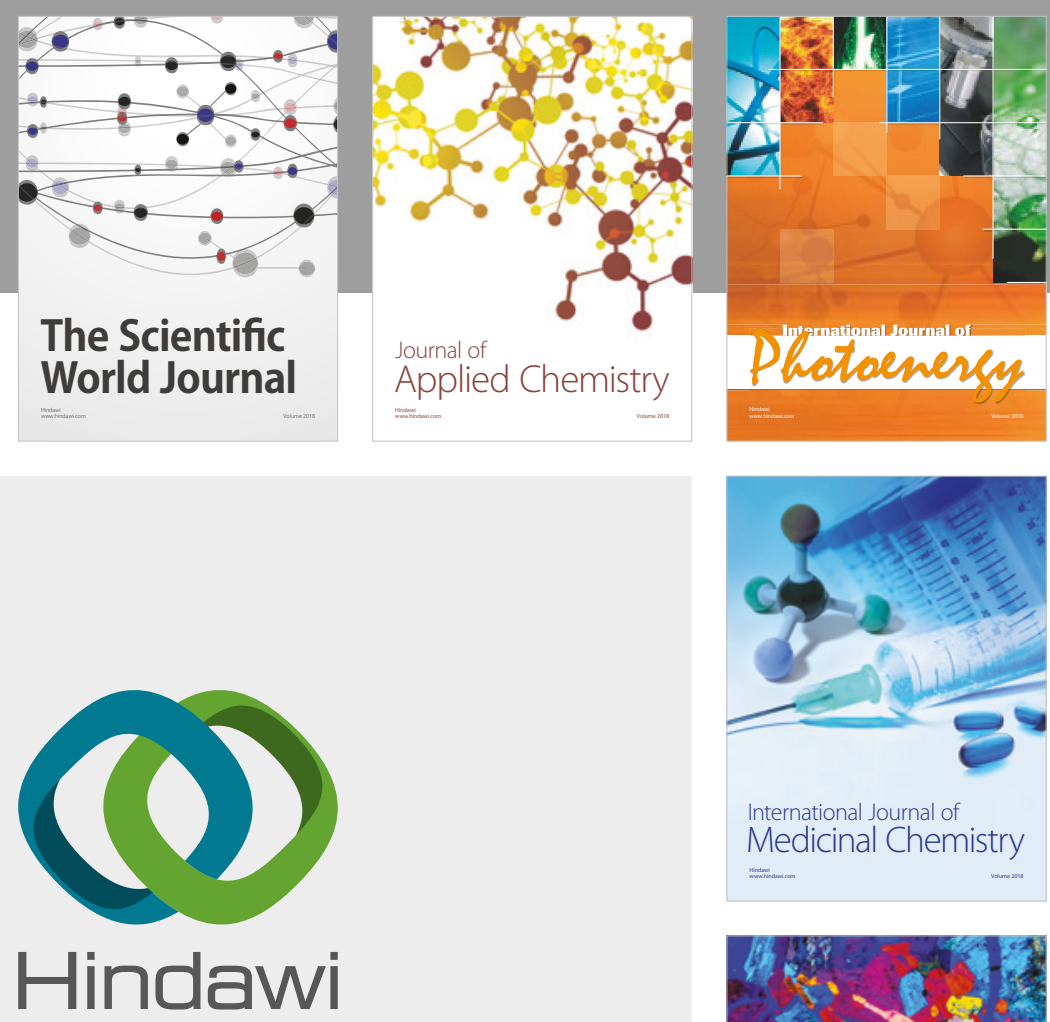

Submit your manuscripts at

www.hindawi.com
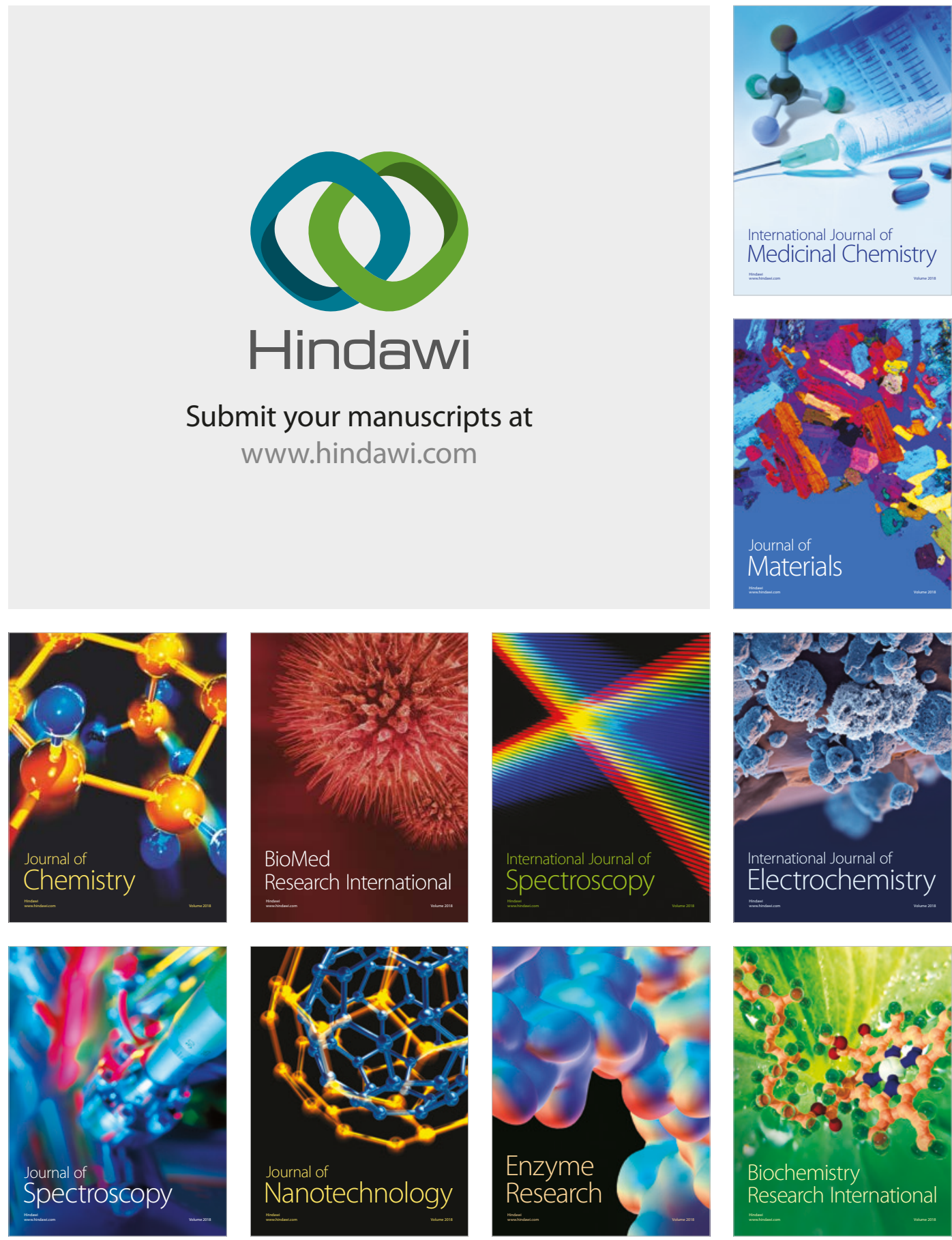
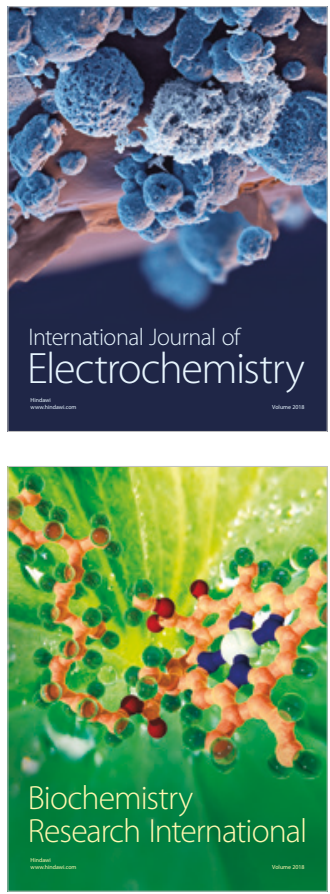